Published in final edited form as:

J Med Chem. 2016 August 25; 59(16): 7690-7695. doi:10.1021/acs.jmedchem.6b00928.

\title{
Development of a Series of (1-Benzyl-3-(6-methoxypyrimidin-3- yl)-5-(trifluoromethoxy)-1H-indol-2-yl)methanols as Selective Protease Activated Receptor 4 (PAR4) Antagonists with in Vivo Utility and Activity Against $\gamma$-Thrombin
}

\author{
Kayla J. Temple ${ }^{\dagger, \ddagger}$, Matthew T. Duvernay ${ }^{\dagger}$, Summer E. Young ${ }^{\dagger}$, Wandong Wen", Wenjun Wu", \\ Jae G. Maeng ${ }^{\dagger}$, Anna L. Blobaum ${ }^{\dagger}, \neq$, Shaun R. Stauffer ${ }^{\dagger, \S}$, Heidi E. Hamm ${ }^{\star}, \dagger$, and Craig W. \\ Lindsley ${ }^{\star}, \dagger, \ddagger, \S$ \\ †Department of Pharmacology, Vanderbilt University School of Medicine, 9281 Wardley Park \\ Lane, Nashville, Tennessee 37232, United States \\ $\mp$ Vanderbilt Center for Neuroscience Drug Discovery, Vanderbilt University School of Medicine, \\ 9281 Wardley Park Lane, Nashville, Tennessee 37232, United States \\ §Department of Chemistry, Vanderbilt University, Nashville, Tennessee 37232, United States \\ "College of Science, Northwest Agriculture \& Forestry University, Yangling, Shaanxi 712100, \\ China
}

\begin{abstract}
Here, we describe the development of a series of highly selective PAR4 antagonists with nanomolar potency and selectivity versus PAR1, derived from the indole-based $\mathbf{3}$. Of these, $\mathbf{9 j}$ $\left(\right.$ PAR4 $\mathrm{IC}_{50}=445 \mathrm{nM}$, PAR1 response $\left.\mathrm{IC}_{50}>30 \mu \mathrm{M}\right)$ and $\mathbf{1 0 h}\left(\mathrm{PAR} 4 \mathrm{IC}_{50}=179 \mathrm{nM}\right.$, PAR1 response $\mathrm{IC}_{50}>30 \mu \mathrm{M}$ ) maintained an overall favorable in vitro DMPK profile, encouraging rat/ mouse in vivo pharmacokinetics (PK) and activity against $\gamma$-thrombin.
\end{abstract}

\section{Graphical abstract}

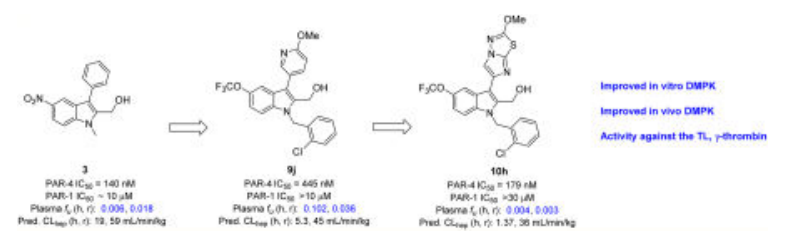

*Corresponding Authors. For H.E.H.: phone, 615-343-9536; fax, 615-343-1084; heidi.hamm@ vanderbilt.edu. For C.W.L.: phone, 615-322-8700; fax, 615-343-3088; craig.lindsley@ vanderbilt.edu.

K.J.T. and M.T.D. contributed equally

ASSOCIATED CONTENT

Supporting Information

The Supporting Information is available free of charge on the ACS Publications website at DOI: 10.1021/acs.jmedchem.6b00928. Experimental procedures and spectroscopic data for selected compounds, detailed pharmacology and DMPK methods (PDF) Molecular formula strings (CSV) 


\section{INTRODUCTION}

Heart attack is the leading cause of death and morbidity in the western world, ${ }^{1}$ with up to one-third of patients experiencing a second event within six months. ${ }^{2}$ The role of platelet activation is reflected by the efficacy of antiplatelet reagents (aspirin + P2Y12 antagonist) in preventing the recurrent thrombosis that causes heart attack and stroke. ${ }^{3,4}$ Despite this progress, $10-12 \%$ of patients on currently available antiplatelet therapeutics will face a second heart attack one year after being treated and a significant risk of bleeding. ${ }^{5-7}$ Thus, there is an urgent need for additional antiplatelet therapeutics to prevent thrombosis without causing bleeding.

Thrombin is the terminal enzyme of the coagulation cascade responsible for platelet activation and the generation of fibrin, essential processes for both thrombosis and hemostasis. Human platelets respond to thrombin through two G protein-coupled receptors, PAR1 and PAR $4 .{ }^{8}$ PAR 1 contains a hirudin like thrombin binding domain and therefore displays higher affinity for thrombin. ${ }^{9} \mathrm{EC}_{50}$ s for PAR1 $(\sim 0.2 \mathrm{nM})$ and PAR4 $(\sim 5 \mathrm{nM})$ differ by more than an order of magnitude, suggesting PAR4 is engaged after PAR1 as the concentration of thrombin increases at the local site of injury.

Thrombin receptor antagonists (TRAs) as a therapeutic alternative have been eagerly anticipated in cardiovascular medicine; vorapaxar is a PAR1 TRA that underwent two phase III clinical trials, TRA $\bullet$ CER,${ }^{10}$ and TRA $2{ }^{\circ} \mathrm{P}^{11,12}$ After safety review, the TRA $\bullet \mathrm{CER}$ trial was halted early and the TRA $2^{\circ} \mathrm{P}$ secondary prevention trial was partially discontinued due to an alarming increase in intracranial hemorrhage. ${ }^{12}$ As a result, attention has turned to PAR4 as a potential target on the platelet that could strike the desired balance between safety and efficacy.

In addition to delayed engagement, PAR4 displays a more robust and sustained responses in the platelet, ${ }^{13}$ suggesting distinct roles for the receptors; contrary to prior convention, recent findings suggest PAR4 is more important for the thrombin-induced procoagulant effect on platelets. ${ }^{13}$ Unfortunately, tool compounds to probe the role of PAR4 in hemostasis and thrombosis have been lacking and the field has relied almost exclusively on PAR4 antibodies. ${ }^{14}$ Additionally, thrombin activates PARs through cleavage of the extracellular domain of the receptor, revealing an encrypted tethered ligand (TL) that binds intramolecularly to activate the receptor. ${ }^{15}$ PARs can also be activated artificially with a synthetic soluble "activating peptide" (AP) corresponding in sequence to the naturally derived TL. ${ }^{15,16}$ Becaue of its covalent nature, the TL is much more difficult to inhibit than AP, but the ability to target TL would be a critical attribute of an in vivo probe molecule.

PAR4 antagonist described to date in the literature (Figure 1), including YD-3 (1), ${ }^{17}$ SEY-3 (2), ${ }^{18}$ and ML354 (3), ${ }^{19}$ proved to be selective versus PAR1 but suffer from both poor DMPK profiles as well as a lack of activity upon $\gamma$-thrombin activation. As we previously reported, the 2-methyl carbinol moiety within $\mathbf{3}$ plays an important role in maintaining potency while reducing lipophilicity, positively impacting free fraction and plasma stability. ${ }^{19} \mathrm{~A}$ unique challenge remaining within $\mathbf{3}$ was the identification of an appropriate electronwithdrawing functionality to replace the aromatic nitro group, as limited success was found 
in our initial campaign (all analogues $\sim 10 \mu \mathrm{M}$ ). ${ }^{19}$ To further address this challenge, we now report the results from ongoing iterative lead optimization efforts within the indole chemotype, leading to compounds with comparable potency and selectivity while improving DMPK profiles and achieving activity against the TL.

\section{RESULTS AND DISCUSSION}

\section{Chemistry}

Our multidimensional optimization approach is summarized in Figure 2, and PAR4 antagonist activity was evaluated through $\alpha_{\mathrm{IIb}} \beta 3$ activation upon PAR4-AP stimulation using a PAC-1 binding assay to drive SAR. ${ }^{20}$ Scheme 1 highlights the four-step route to access analogues $\mathbf{8}$, surveying diversity at three positions. ${ }^{20}$ Here, bromination of commercial 5- or 6-substituted indoles $\mathbf{4}$ occurred smoothly, affording 3-bromo congeners 5 in $90-99 \%$ yield. Suzuki couplings with aryl or heteroaryl boronic acids afforded analogues 6 in good yields, followed by alkylation to deliver derivatives 7. Finally, LAH reduction of the esters provided putative PAR4 antagonists 8 in yields ranging from 50 to $85 \%$. Initially, we held the 3-positon constant with a 2-methoxypyridine moiety, providing analogues $\mathbf{9}$, as this 3-position substituent showed modest activity $(\sim 10 \mu \mathrm{M})$ in analogues lacking the 5- $\mathrm{NO}_{2}$ group. If a competent $\mathrm{NO}_{2}$ replacement could be identified in the context of the 2methoxypyridine moiety, we hoped to see an increase in PAR4 activity.

Our screening strategy relied on an initial single-point screen at $10 \mu \mathrm{M}$ and assessing the maximum \% of PAC-1 binding, followed by full concentration-response curves (CRCs) to determine PAR4 $\mathrm{IC}_{50} \mathrm{~s}$. As shown in Table 1, initial SAR for series 9 was steep, with $\mathrm{NO}_{2}$ replacements such as $\mathrm{CF}_{3}(\mathbf{9 a}$ and $\mathbf{9 d})$ and, in many cases, $\mathrm{OCF}_{3}(\mathbf{9 b}, 9 \mathbf{c}, 9 \mathbf{e}$, and $9 \mathbf{h})$ being devoid of PAR4 activity. Moreover, the nature of the benzyl moiety was critically important for PAR4 inhibitory activity. For example, 9f, with a 2,4-diF benzyl group, displayed submicromolar activity $\left(\mathrm{IC}_{50}=820 \mathrm{nM}\right)$, highlighting that the undesirable $5-\mathrm{NO}_{2}$ moiety could be replaced while maintaining PAR4 activity. However, the most potent analogue in this initial series 9 was $\mathbf{9 j}$, a 2-Cl benzyl derivative, with an $\mathrm{IC}_{50}$ of $445 \mathrm{nM}$.

Having identified optimal benzyl moieties in analogues $\mathbf{9}$, our next SAR exploration focused on the identification of alternate heterocyclces for the 2-methoxypyridine in analogues $\mathbf{1 0}$ (Table 2). Here, a more basic, unsubstituted 4-pyridyl analogue, 10a, was inactive as was an unsubstituted pyrimidine 10b. Interestingly, introduction of either a alkoxy group or a thiomethyl moiety to the 2-position of the pyrimidine core, as in $\mathbf{1 0 c}-\mathbf{g}$, restored PAR4 inhibition; however, PAR4 $\mathrm{IC}_{50} \mathrm{~s}$ varied from $490 \mathrm{nM}(\mathbf{1 0 d})$ to $>10 \mu \mathrm{M}$ (10f). Introduction of either the 2-methoxy or a 2-thiomethoxy group had significant impact. Comparison of $\mathbf{1 0 b}$ $\left(\mathrm{IC}_{50}>10 \mu \mathrm{M}\right)$ to $10 \mathbf{c}\left(\mathrm{IC}_{50}=1.49 \mu \mathrm{M}\right)$ and $\mathbf{1 0 b}\left(\mathrm{IC}_{50}>10 \mu \mathrm{M}\right)$ to $10 \mathbf{e}\left(\mathrm{IC}_{50}=1.50 \mu \mathrm{M}\right)$ highlights how this small polar moiety enhances PAR4 inhibition. As we were concerned that 2-substituted pyrimidines with OMe or SMe functionalities may be electrophilic in vivo and be displaced by biological nucleophiles, we also surveyed a variety of pyrimidine replacements and found that only a 2-methoxy-6-methylimidazo[2,1-b][1,3,4]thiadiazole bicyclic ring system, as in 10h, was active. Moreover, it was the most potent analogue made in the series $\left(\mathrm{PAR} 4 \mathrm{IC}_{50}=179 \mathrm{nM}\right)$ and on par with 3. Recently, Bristol-Myers Squibb 
disclosed a novel benzofuran-based series of PAR4 antagonists (Figure 3), exemplified by $\mathbf{1 2}$ (BMS986120), that also possesses the 2-methoxy-6-methylimidazo[2,1-b][1,3,4]thiadiazole bicyclic ring system. ${ }^{21}$

Finally, we elected to explore the impact of 6- versus 5-substiuents on the indole core in analogues 11 (Table 3), as this had never been assessed. Interestingly, simple alkoxy moieties (11a-c) did afford modest PAR4 inhibition, but once again, the 6-OCF 3 group, in the context of 2-OMe and 2-SMe pyrimidines, $11 \mathrm{~d}\left(\mathrm{IC}_{50}=930 \mathrm{nM}\right)$ and $11 \mathrm{e}\left(\mathrm{IC}_{50}=210\right.$ $\mathrm{nM}$ ), respectively, showed submicromlar potency. Thus, multiple new PAR4 antagonists resulted that proved worthy of further profiling.

\section{Molecular Pharmacology}

Of the six submicromolar PAR4 antagonists identified (9f, 9j, 10d, 10h, 11d, and 11e), all were selective versus the key antitarget PAR1 $\left(\mathrm{IC}_{50} \mathrm{~s}>30 \mu \mathrm{M}\right)$. On the basis of physiochemical and DMPK data (vide infra), only $\mathbf{9 j}$ and $\mathbf{1 0 h}$ were subjected to more detailed molecular pharmacology profiling. As shown in Figure 4A, $\mathbf{9 j}$ was an equipotent PAR4 antagonist at both assay readouts (both PAC-1, $\mathrm{IC}_{50}=445 \mathrm{nM}$, and P-Selectin, $\mathrm{IC}_{50}=$ $435 \mathrm{nM}$ ). A progressive fold-shift inhibition assay/Schild analysis with 9j (Figure 4B) displayed an unexpected mixed competitive/noncompetitive mode of PAR4 inhibition with neither a clean, parallel rightward shift in the concentration-response curve (competitive) nor a defined decrease in AP-max (noncompetitive). Similarly, 10h displayed comparable PAR4 antagonism (Figure 4C) at both assay readouts (both PAC-1, $\mathrm{IC}_{50}=179 \mathrm{nM}$, and PSelectin, $\mathrm{IC}_{50}=132 \mathrm{nM}$ ). However, a progressive fold-shift inhibition assay/Schild analysis with 10h (Figure 4D) displayed a similar, complex mode of inhibition yet clearly more potent. The mixed mechanism of PAR4 inhibition is intriguing and suggests with further SAR exploration that it might be possible to develop both competitive and noncompetitive inhibitors of PAR4 and then validate each in vivo. In addition, both $\mathbf{9 j}$ and $\mathbf{1 0 h}$ were devoid of activity at PAR $1\left(\mathrm{IC}_{50} \mathrm{~s}>30 \mu \mathrm{M}\right)$.

As mentioned earlier, no small molecule PAR4 antagonist reported to date has demonstrated PAR4 inhibition against the tethered ligand (TL). As an ideal tool compound that would possess activity against the TL, we evaluated the ability of both $\mathbf{9 j}$ and $\mathbf{1 0 h}$ to inhibit PAR4 when activated by $100 \mathrm{nM} \gamma$-thrombin (Figure 5). While the results with $\mathbf{9 j}$ were variable and weak $\left(\mathrm{IC}_{50}>10 \mu \mathrm{M}\right.$ with P-Selectin and $\mathrm{IC}_{50}=9.4 \mu \mathrm{M}, 48.7 \%$ max inhibition with PAC-1), efficacy was noted against the TL. However, $\mathbf{1 0 h}$ proved far more effective against the TL, affording comparable inhibition ( $\mathrm{IC}_{50} \mathrm{~s}$ of $4.35 \mu \mathrm{M}$ and $39.4 \%$ maximum inhibition). Thus, while weak partial antagonists against the TL, $9 \mathbf{j}$ and $\mathbf{1 0 h}$ represent the first reported small molecule PAR4 antagonists to have activity within the indole-based series.

\section{DMPK Disposition Attributes}

Of the six submicromolar PAR4 antagonists identified (9f, 9j, 10d, 10h, 11d, and 11e), 9f, 11d, and 11e quickly fell out of contention as in vivo probes due to either high plasma protein binding (rat and human $f_{\mathrm{u}}<0.001$ ) or high predicted in vitro clearance in microsomes that was equal to or greater than hepatic blood flow (rat $\mathrm{CL}_{\mathrm{hep}}>60 \mathrm{~mL} / \mathrm{min} / \mathrm{kg}$ and human $\mathrm{CL}_{\text {hep }}>20 \mathrm{~mL} / \mathrm{min} / \mathrm{kg}$ ). ${ }^{20}$ Table 4 highlights representative physiochemical and 
DMPK profiles of $\mathbf{9 j}, \mathbf{1 0 d}$, and $\mathbf{1 0 h}$. We were concerned about the lability of the 2-SMe pyrimidine moiety in 10d, and this concern was born out, as 10d showed little fraction unbound in rat or human plasma and predicted hepatic clearance near blood flow in each species and superhepatic clearance in vivo. In contrast, the pyrimidine bioisostere $\mathbf{1 0 h}$ displayed low predicted hepatic clearance in human microsomes $\left(\mathrm{CL}_{\mathrm{hep}}=1.1 \mathrm{~mL} / \mathrm{min} / \mathrm{kg}\right)$ and low to moderate in rat $\left(\mathrm{CL}_{\mathrm{hep}}=36.1 \mathrm{~mL} / \mathrm{min} / \mathrm{kg}\right)$. In vivo rat $\mathrm{PK}$ showed a $6.1 \mathrm{~h}$ halflife with moderate clearance $\left(\mathrm{CL}_{\mathrm{p}}=45 \mathrm{~mL} / \mathrm{min} / \mathrm{kg}\right)$; however, $10 \mathrm{~h}$ was highly protein bound in both species. PAR4 antagonist $\mathbf{9 j}$ represented middle ground between the $\mathbf{1 0 d}$ and $\mathbf{1 0 h}$. Analogue 9j displayed low predicted hepatic clearance in human microsomes $\left(\mathrm{CL}_{\mathrm{hep}}=5.3\right.$ $\mathrm{mL} / \mathrm{min} / \mathrm{kg})$ and moderate in rat $\left(\mathrm{CL}_{\mathrm{hep}}=45.1 \mathrm{~mL} / \mathrm{min} / \mathrm{kg}\right)$, and the best free drug levels to date (human $f_{\mathrm{u}}=0.10$, rat $f_{\mathrm{u}}=0.04$ ). In vivo rat PK showed a $2.8 \mathrm{~h}$ half-life with high total plasma clearance $\left(\mathrm{CL}_{\mathrm{p}}=118 \mathrm{~mL} / \mathrm{min} / \mathrm{kg}\right)$ and a high volume of distribution at steady state ( $V_{\mathrm{ss}}=21.4 \mathrm{~L} / \mathrm{kg}$ ). As mouse is the species in which the thrombosis models are performed, and in which PAR4 is expressed on platelets, we performed an IV PK study $(0.2 \mathrm{mg} / \mathrm{kg}$, PEG:saline (1:1) for $\mathbf{9 j}$ in five male c57b1/6 mice to mimic the route of administration in these models. Plasma levels of $\mathbf{9 j}$ were collected at a single 40 min time point and were incredibly consistent (plasma $450 \pm 20 \mathrm{ng} / \mathrm{mL}, 1000 \pm 50 \mathrm{nM}$ ) and above the in vitro $\mathrm{IC}_{50}$ of $\mathbf{9 j}$. When corrected for free drug levels, the unbound plasma concentration of $\mathbf{9 j}$ was reduced to $\sim 38 \mathrm{nM}$; however, a question to be addressed in later studies and with more refined PAR4 inhibitors is if efficacy will be driven by total or free drug levels in plasma.

\section{CONCLUSION}

In summary, we report significant advances in the field of small molecule PAR4 antagonists relative to the known art 1-3, for which we have addressed the plasma instability of $\mathbf{1}$ and $\mathbf{2}$ and found suitable replacements for the aromatic nitro group of 3. New PAR4 antagonists described here have also lowered plasma protein binding (increased fraction unbound, e.g., free drug principle) as well as both improved in vitro and in vivo DMPK such that $\mathbf{9 j}$ may serve as a first-generation PAR4 in vivo tool. Importantly, both $\mathbf{9 j}$ and $\mathbf{1 0 h}$ are the first reported indole-based small molecules to show PAR4 inhibitory activity against the native ligand, $\gamma$-thrombin, and were inactive against PAR1 $\left(\mathrm{IC}_{50} \mathrm{~s}>30 \mu \mathrm{M}\right)$. Finally, the mode of inhibition for $\mathbf{9 j}$ and $\mathbf{1 0 h}$ is complex, showing a mixed competitive/noncompetitive mechanism of action, suggesting it might be possible to develop both competitive and noncompetitive PAR4 antagonists. Additional refinements and in vivo studies are in progress and will be reported in due course.

\section{EXPERIMENTAL SECTION}

\section{Chemistry}

The general chemistry, experimental information, and syntheses of all other compounds, including 10h, are supplied in the Supporting Information, as well as pharmacology and DMPK methods. 
(1-(2-Chlorobenzyl)-3-(6-methoxypyridin-3-yl)-5-(trifluoromethoxy)-1H-indol-2-yl)methanol (9j): Ethyl 3-bromo-5-(trifluoromethoxy)-1H-indole-2-carboxylate

To a THF solution (3 mL) of commercially available ethyl 5-(trifluoromethoxy)- $1 \mathrm{H}$ indole-2-carboxylate (300 mg, $1.098 \mathrm{mmol}, 1$ equiv) was added dropwise the THF (5 mL) solution of NBS (214.7 mg, $1.206 \mathrm{mmol}, 1.1$ equiv). The mixture was stirred at room temperature for $2 \mathrm{~h}$. Then THF was removed under reduced pressure and the crude product was purified via ISCO flash chromatography (0-10\% ethyl acetate in hexane) (382 mg, 99\%). LCMS: $R_{\mathrm{T}}=1.276 \mathrm{~min}, \mathrm{MS}\left(\mathrm{ESI}^{+}\right) \mathrm{m} / \mathrm{z}=351.8[\mathrm{M}+\mathrm{H}]^{+} .{ }^{1} \mathrm{H} \mathrm{NMR}(400.1 \mathrm{MHz}$, $\left.\mathrm{CDCl}_{3}\right): 1.46(\mathrm{t}, J=7.1,3 \mathrm{H}), 4.44-4.50(\mathrm{q}, J=7.1,2 \mathrm{H}), 7.23(\mathrm{~d}, J=1.4,1 \mathrm{H}), 7.38-7.42$ $(\mathrm{dd}, J=4.7,8.9,1 \mathrm{H}), 7.53(\mathrm{~d}, J=16.1,1 \mathrm{H}), 9.12(\mathrm{~s}, 1 \mathrm{H})$.

\section{Ethyl 3-(6-Methoxypyridin-3-yl)-5-(trifluoromethoxy)-1H-indole-2-carboxylate}

To a microwave vial was added ethyl 3-bromo-5-(trifluoromethoxy)-1 $H$-indole-2carboxylate (300 mg, $0.852 \mathrm{mmol}, 1$ equiv), 6-methoxy-3-pyridinyl-boronic acid (169.5 mg, $1.107 \mathrm{mmol}, 1.3$ equiv), $\mathrm{Pd}\left(\mathrm{PPh}_{3}\right)_{4}$ (98.5 mg, $0.085 \mathrm{mmol}, 0.1$ equiv), $\mathrm{Na}_{2} \mathrm{CO}_{3}$ (180.6 mg, $1.704 \mathrm{mmol}, 2$ equiv), DMF (4 mL), and water $(1 \mathrm{~mL})$. The vial was sealed and put in the microwave reactor and then heated for $15 \mathrm{~min}$ at $120^{\circ} \mathrm{C}$. On completion, the solvents were passed through a Celite pad. The solvents were removed under reduced pressure and pure 3(6-methoxypyridin-3-yl)-5-(trifluoromethoxyl)-1 $H$-indole-2-carboxylate was afforded; ISCO flash chromatography (0-20\% ethyl acetate in hexane) (253.2 mg, 78\%). LCMS: $R_{\mathrm{T}}=1.233$ $\min . \mathrm{MS}\left(\mathrm{ESI}^{+}\right) \mathrm{m} / \mathrm{z}=380.8[\mathrm{M}+\mathrm{H}]^{+} .{ }^{1} \mathrm{H} \mathrm{NMR}\left(400.1 \mathrm{MHz}, \mathrm{CDCl}_{3}\right): 1.27(\mathrm{t}, J=7.1,3 \mathrm{H})$, 4.05 (s, 3H), 4.29-4.34 (q, $J=7.1,2 \mathrm{H}), 6.90(\mathrm{~d}, J=8.5,1 \mathrm{H}), 7.26-7.27(\mathrm{~m}, 1 \mathrm{H}), 7.43$ (s, $1 \mathrm{H}), 7.45(\mathrm{~d}, J=9.0,1 \mathrm{H}), 7.81-7.84(\mathrm{dd}, J=2.4,8.5,1 \mathrm{H}), 8.37(\mathrm{~d}, J=2.1,1 \mathrm{H}), 9.1(\mathrm{~s}, 1 \mathrm{H})$.

\section{(1-(2-Chlorobenzyl)-3-(6-methoxypyridin-3-yl)-5-(trifluoromethoxy)-1 H-indol-2-yl)methanol} (9j)

To a dry vial was added 3-(6-methoxypyridin-3-yl)-5-(trifluoromethoxyl)-1 $H$-indole-2carboxylate (10 $\mathrm{mg}, 0.039 \mathrm{mmol}, 1$ equiv), a series of 2-chlorobenzyl bromide (1.5 equiv), $\mathrm{K}_{2} \mathrm{CO}_{3}(5.5 \mathrm{mg}, 0.078 \mathrm{mmol}, 2$ equiv), and DMF. The mixture was stirred at room temperature for $18 \mathrm{~h}$. The desired indole esters were purified by the Gilson reverse-phase preparative $\mathrm{LC}\left(\mathrm{CH}_{3} \mathrm{CN} / \mathrm{H}_{2} \mathrm{O} / \mathrm{TFA}\right)$. To the solution of the indole esters in THF was added LAH ( $1 \mathrm{M}$ in THF) ( 2 equiv) at $0{ }^{\circ} \mathrm{C}$, and the solution was allowed to stir for $1 \mathrm{~h}$. Then, $2 \mathrm{~N}$ $\mathrm{HCl}$ aqueous $(10 \mu \mathrm{L})$ was added to consume the remaining $\mathrm{LAH}$, followed by addition of 10 $\mu \mathrm{L}$ of saturated $\mathrm{NaHCO}_{3}$ aqueous. The solvents of reaction were removed on a heated airblowing block, and then the title compound was purified by the Gilson reverse-phase preparative LC, with $>95 \%$ purity by UV215 nm, UV254 nm, and ELSD analysis on LCMS. LCMS: $R_{\mathrm{T}}=1.229 \mathrm{~min} . \mathrm{MS}\left(\mathrm{ESI}^{+}\right) \mathrm{m} / z=463.0[\mathrm{M}+\mathrm{H}]^{+}$. ${ }^{1} \mathrm{H}$ NMR $(400.1 \mathrm{MHz}$, DMSO$\left.d_{6}\right): 3.84(\mathrm{~s}, 1 \mathrm{H}), 3.93(\mathrm{~s}, 3 \mathrm{H}), 4.51(\mathrm{~s}, 2 \mathrm{H}), 5.71(\mathrm{~s}, 2 \mathrm{H}), 6.33-6.35(\mathrm{~m}, 1 \mathrm{H}), 6.98-7.01(\mathrm{dd}$, $J=0.5,8.5,1 \mathrm{H}), 7.16-7.20(\mathrm{~m}, 2 \mathrm{H}), 7.28-7.31(\mathrm{~m}, 1 \mathrm{H}), 7.45-7.48(\mathrm{~m}, 2 \mathrm{H}), 7.54-7.56(\mathrm{~m}$, $1 \mathrm{H}), 7.91-7.94(\mathrm{dd}, J=2.5,8.5,1 \mathrm{H}), 8.36(\mathrm{~d}, J=1.8,1 \mathrm{H}) .{ }^{13} \mathrm{C}$ NMR (DMSO- $\left.d_{6}\right): 162.4$, 146.7, 142.7, 140.1, 138.6, 135.0, 134.7, 131.0, 129.3, 128.8, 127.6, 127.5 (q, $J=259.6$ ), 127.3, 126.7, 122.7, 116.2, 112.1, 111.5, 111.2, 110.6, 53.2, 53.0, 48.7. HRMS (TOF, ES+) $\mathrm{C}_{23} \mathrm{H}_{19} \mathrm{ClF}_{3} \mathrm{~N}_{2} \mathrm{O}_{3}[\mathrm{M}+\mathrm{H}]^{+}$calcd mass 463.1031 , found 463.1035 . 


\section{Supplementary Material}

Refer to Web version on PubMed Central for supplementary material.

\section{Acknowledgments}

Dr. Lindsley thanks William K. Warren, Jr. and the William K. Warren Foundation who funded the William K. Warren, Jr. Chair in Medicine, and for support of our research. This work was generously supported by the NIH (NS081669 and NS082198)

\section{ABBREVIATIONS USED}

$\begin{array}{ll}\text { PAR4 } & \text { selective protease activated receptor } 4 \\ \text { CRC } & \text { concentration-response-curve } \\ \text { PPB } & \text { plasma protein binding }\end{array}$

\section{References}

1. Grech ED, Ramsdale DR. Acute coronary syndrome: unstable angina and non-ST segment elevation myocardial infarction. BMJ. 2003; 326:1259-1261. [PubMed: 12791748]

2. Collinson J, Flather MD, Fox KAA, Findlay I, Rodrigues E, Dooley P, Ludman P, Adgey J, Bowker TJ, Mattu R. Clinical outcomes, risk stratification and practice patterns of unstable angina and myocardial infarction without ST elevation: Prospective Registry of Acute Ischaemic Syndromes in the UK (PRAIS-UK). Eur. Heart J. 2000; 21:1450-1457. [PubMed: 10952837]

3. Patrono C. Prevention of myocardial infarction and stroke by aspirin: different mechanisms? Different dosage? Thromb. Res. 1998; 92:S7-12. [PubMed: 9781831]

4. Bowry AD, Brookhart MA, Choudhry NK. Meta-analysis of the efficacy and safety of clopidogrel plus aspirin as compared to antiplatelet monotherapy for the prevention of vascular events. Am. J. Cardiol. 2008; 101:960-966. [PubMed: 18359315]

5. Harker LA, Boissel JP, Pilgrim AJ, Gent M. Comparative safety and tolerability of clopidogrel and aspirin: results from CAPRIE. CAPRIE Steering Committee and Investigators. Clopidogrel versus aspirin in patients at risk of ischaemic events. Drug Saf. 1999; 21:325-335. [PubMed: 10514023]

6. Yusuf S, Zhao F, Mehta SR, Chrolavicius S, Tognoni G, Fox KK. Clopidogrel in unstable angina to prevent recurrent events trial, I. Effects of clopidogrel in addition to aspirin in patients with acute coronary syndromes without ST-segment elevation. N. Engl. J. Med. 2001; 345:494-502. [PubMed: 11519503]

7. Sabatine MS, Cannon CP, Gibson CM, Lopez-Sendon JL, Montalescot G, Theroux P, Claeys MJ, Cools F, Hill KA, Skene AM, McCabe CH, Braunwald E. CLARITY-TIMI 28 Investigators. Addition of clopidogrel to aspirin and fibrinolytic therapy for myocardial infarction with STsegment elevation. N. Engl. J. Med. 2005; 352:1179-1189. [PubMed: 15758000]

8. Kahn ML, Nakanishi-Matsui M, Shapiro MJ, Ishihara H, Coughlin SR. Protease-activated receptors 1 and 4 mediate activation of human platelets by thrombin. J. Clin. Invest. 1999; 103:879-887. [PubMed: 10079109]

9. Vu TK, Wheaton VI, Hung DT, Charo I, Coughlin SR. Domains specifying thrombin-receptor interaction. Nature. 1991; 353:674-677. [PubMed: 1717851]

10. Harrington RA, Van de Werf F, Armstrong PW, Aylward P, Park B, Veltri E, Mahaffey KW, Moliterno DJ, Strony J, Wallentin L, White HD, Diaz R, Aylward P, Huber K, Van de Werf F, Nicolau JC, Armstrong PW, Prieto JC, Isaza D, Grande P, Nieminen M, Montalescot G, Bode C, Wong L, Ofner P, Lewis BS, Ambrosio G, Valgimigli M, Ogawa H, Yamaguchi T, Jukema JW, Cornel JH, White HD, Nordrehaug JE, Ruzyllo W, Providencia L, Tan HC, Dalby A, Seung-Jung P, Betriu A, Cequier A, Held C, Pfisterer M, Chen MF, Timukaynak T, Storey RF, Chen E, Harrington RA, Hudson MP, Lincoff AM, Mahaffey KW, Morrow DA, Tricoci P, Whellan D. The 
thrombin receptor antagonist for clinical event reduction in acute coronary syndrome (TRA*CER) trial: study design and rational. Am. Heart J. 2009; 158:327-334. [PubMed: 19699853]

11. Scirica BM, Bonaca MP, Braunwald E, De Ferrari GM, Isaza D, Lewis BS, Mehrhof F, Merlini PA, Murphy SA, Sabatine MS, Tendera M, Van de Werf F, Wilcox R, Morrow DA. for the TRA $2^{\circ} \mathrm{P}-$ TIMI 50 Steering Committee Investigators. Vorapaxar for secondary prevention of thrombotic events for patients with previous myocardial infarction: a prespecified subgroup analysis of the TRA 2 degrees P-TIMI 50 trial. Lancet. 2012; 380:1317-1324. [PubMed: 22932716]

12. Tricoci P, Huang Z, Held C, Moliterno D, Armstrong P, Van de Werf F, White H, Aylward P, Wallentin L, Chen E, Lokhnygina Y, Pei J, Leonardi S, Rorick T, Kilian A, Jennings L, Ambrosio G, Bode C, Cequier A, Cornel J, Diaz R, Erkan A, Huber K, Hudson M, Jiang L, Jukema J, Lewis B, Lincoff A, Montalescot G, Nicolau J, Ogawa H, Pfisterer M, Prieto J, Ruzyllo W, Sinnaeve P, Storey R, Valgimigli M, Whellan D, Widimsky P, Strony J, Harrington R, Mahaffey K. CLARITY-TIMI 28 Investigators. Thrombin-receptor antagonist vorapaxar in acute coronary syndromes. N. Engl. J. Med. 2012; 366:20-33. [PubMed: 22077816]

13. Lindahl TL, Macwan AS, Ramstrom S. PAR4 is more important than PAR1 for the thrombininduced procoagulant effect on platelets. J. Thromb. Haemostasis. 2016; doi: 10.1111/jth.13374

14. Duvernay M, Young S, Gailani D, Schoenecker J, Hamm HE. Protease-activated receptor (PAR) 1 and PAR4 differentially regulate factor V expression from human platelets. Mol. Pharmacol. 2013; 83:781-792. [PubMed: 23307185]

15. Vu TK, Hung DT, Wheaton VI, Coughlin SR. Molecular cloning of a functional thrombin receptor reveals a novel proteolytic mechanism of receptor activation. Cell. 1991; 64:1057-1068. [PubMed: 1672265]

16. Xu WF, Andersen H, Whitmore TE, Presnell SR, Yee DP, Ching A, Gilbert T, Davie EW, Foster DC. Cloning and characterization of human protease-activated receptor 4. Proc. Natl. Acad. Sci. U. S. A. 1998; 95:6642-6646. [PubMed: 9618465]

17. Lee F-Y, Lien J-C, Huang J-L, Huang T-M, Tsai S-C, Teng C-M, Wu C-C, Cheng F-C, Kuo S-C. Synthesis of 1-benzyl-3-(5'-hydroxymethyl-2' ${ }^{\prime}$-furyl)indazole analogues as novel antiplatelet agents. J. Med. Chem. 2001; 44:3746-3749. [PubMed: 11606139]

18. Young SE, Duvernay MT, Schulte ML, Lindsley CW, Hamm HE. Synthesis and characterization of indole-derived protease activated receptor 4 antagonists and characterization in human platelets. PLoS One. 2013; 8:e65528. [PubMed: 23776495]

19. Wen W, Young SE, Duvernay MT, Schulte ML, Nance KD, Melancon BJ, Engers J, Locuson CW, Wood MR, Daniels JS, Wu W, Lindsley CW, Hamm HE, Stauffer SR. Substituted indoles as selective protease activated receptor 4 (PAR-4) antagonists: Discovery and SAR of ML354. Bioorg. Med. Chem. Lett. 2014; 24:4708-4713. [PubMed: 25176330]

20. See the Supporting Information for full experimental details on the chemistry and compound characterization, molecular pharmacology and DMPK protocols.

21. (a) Halford B. New drug candidates in San Diego. Chem. Eng. News. 2016; 94:22-23.(b) Banville, J., Remillard, R., Ruediger, EH., Deon, DH., Gagnon, M., Dube, L., Guy, J., Priestly, ES., Posy, S., Maxwell, BD., Wong, PC. Preparation of imidazothiadiazole derivatives and analogs for use as protease activated receptor 4 inhibitors. WO2013163279A1. 2013. (c) Priestly, ES., Posy, SL., Tremblay, FT., Martel, A., Marinier, A. Preparation of imidazothiadiazole derivatives and analogs for use as protease activated receptor 4 inhibitors. WO2013163241A1. 2013. (d) Lawrence, MR., Miller, MM., Seiffert, DA., Posy, SL., Wong, PC., Banville, J., Ruediger, EH., Deon, DH., Martel, A., Tremblay, F., Guy, J., Lavallee, J-F., Gagnon, M. Preparation of imidazothiadiazole derivatives as protease activated receptor 4 (PAR4) inhibitors for treating platelet aggregation. WO2013163244A1. 2013. 


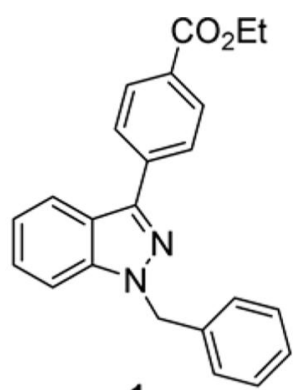

1

PAR4 $I_{50}=130 \mathrm{nM}$

PAR1 $\mathrm{IC}_{50}>10 \mu \mathrm{M}$

PPB $f_{u}(\mathrm{~h}, \mathrm{r})$ : unstable

Pred. $\mathrm{CL}_{\text {hep }}(\mathrm{h}, \mathrm{r}): 16,66 \mathrm{~mL} / \mathrm{min} / \mathrm{kg}$

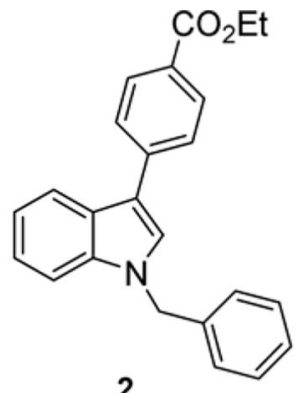

2

PAR4 IC ${ }_{50}=66 \mathrm{nM}$

PAR1 IC ${ }_{50}>10 \mu \mathrm{M}$

PPB $f_{u}(\mathrm{~h}, \mathrm{r})$ : unstable

Pred. $\mathrm{CL}_{\text {hep }}(\mathrm{h}, \mathrm{r}): 17,66 \mathrm{~mL} / \mathrm{min} / \mathrm{kg}$

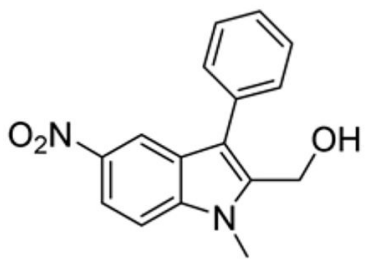

3

$$
\text { PAR4 IC } 50=140 \mathrm{nM}
$$$$
\text { PAR1 IC } 50 \sim 10 \mu \mathrm{M}
$$

Plasma $f_{u}(\mathrm{~h}, \mathrm{r}, \mathrm{m}): 0.006,0.018,0.009$

Pred. $\mathrm{CL}_{\text {hep }}(\mathrm{h}, \mathrm{r}): 19,59 \mathrm{~mL} / \mathrm{min} / \mathrm{kg}$

Figure 1.

Structures and properties of reported PAR-4 antagonists. 


\section{Substitutents}

(3)

Alternative Electron-withdrawing group to improve DMPK profile
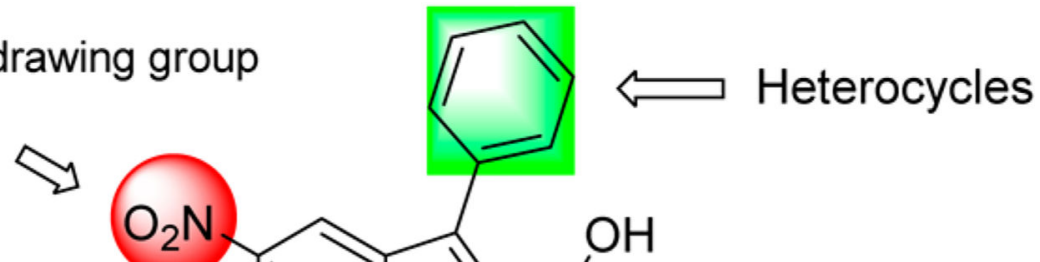

3

Figure 2.

Library optimization strategy for $\mathbf{3}$ to improve PAR4 antagonist activity, selectivity, and the DMPK profile. 
<smiles>COc1nn2cc(-c3c(CO)n(Cc4ccccc4Cl)c4ccc(OC(F)(F)F)cc34)nc2s1</smiles>

$10 \mathrm{~h}$

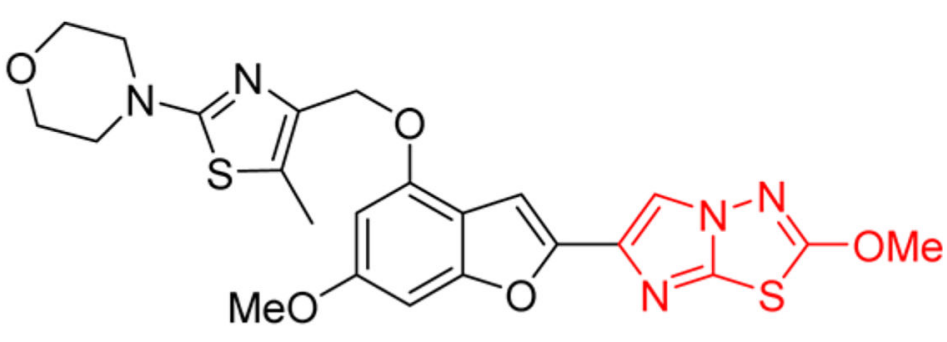

12, BMS986120

Figure 3.

Structures of 10h and 12, PAR4 anatgonists containing the-methoxy-6-methylimidazo[2,1b] $[1,3,4]$ thiadiazole bicyclic ring system. 


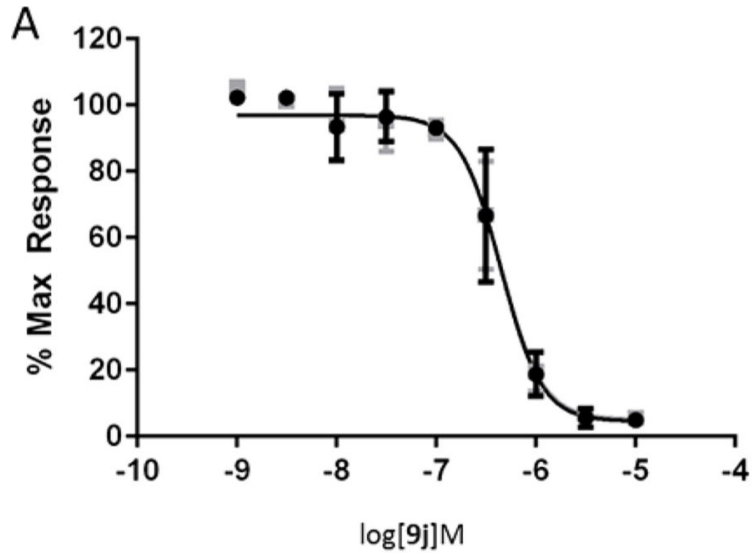

B

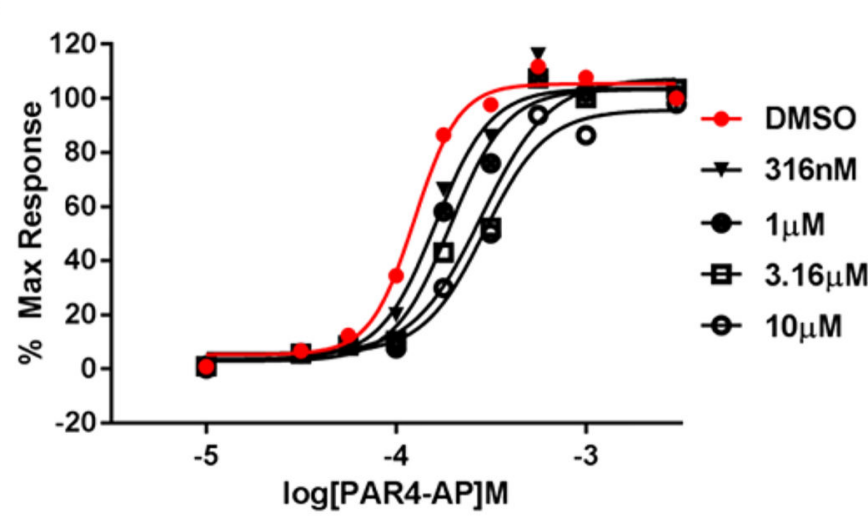

C

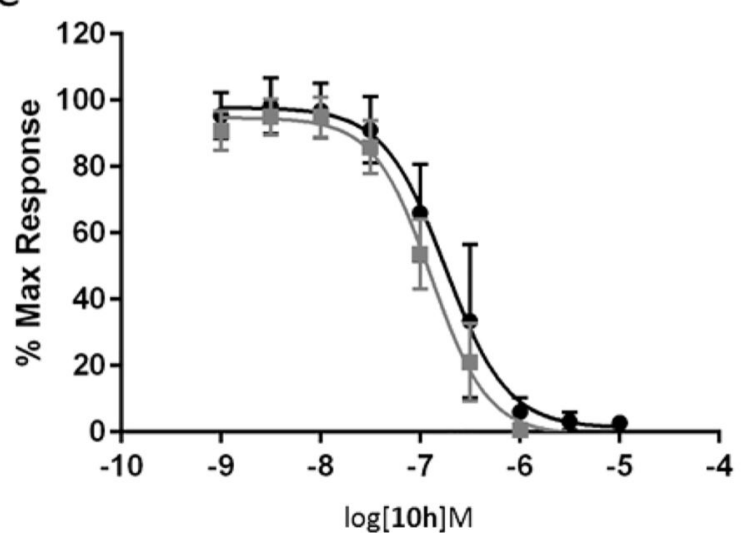

D

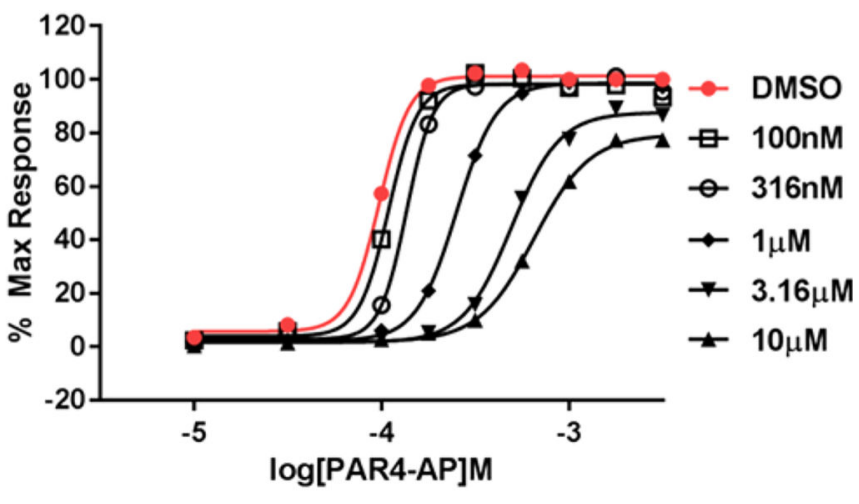

Figure 4.

Molecular pharmacology profile of $\mathbf{9 j}$ and $\mathbf{1 0 h}$. (A) PAR4-AP concentration-response curves $(n=3)$ with equivalent inhibition of both PAC-1 $\left(\mathrm{IC}_{50}=445 \mathrm{nM}\right)$ and P-Selectin $\left(\mathrm{IC}_{50}=435 \mathrm{nM}\right)$. (B) Progressive fold-shift inhibition assay with $\mathbf{9 j}$, showing complex mode of PAR4 inhibition. (C) PAR4-AP concentration-response curves $(n=3)$ with comparable inhibition of both PAC-1 $\left(\mathrm{IC}_{50}=179 \mathrm{nM}\right)$ and P-Selectin $\left(\mathrm{IC}_{50}=132 \mathrm{nM}\right)$. (D) Progressive fold-shift inhibition assay with $\mathbf{1 0 h}$, also showing a complex mode of PAR4 inhibition. Note: compound solubility was not an issue at the concentrations evaluated, i.e., no precipitate was observed. 

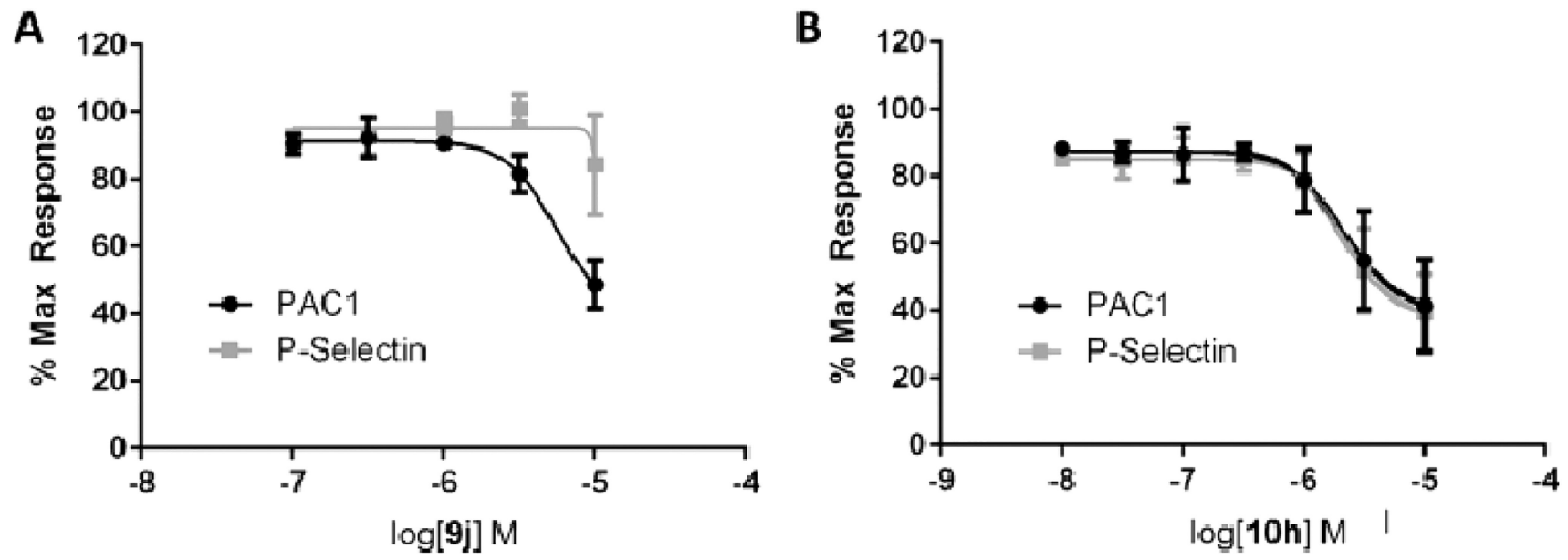

Figure 5.

Molecular pharmacology profile of (A) $9 \mathbf{j}$ and (B) 10h against activation of PAR4 with the tethered ligand, $100 \mathrm{nM} \gamma$-thrombin. 
<smiles></smiles>

4<smiles>CCOC(=O)c1[nH]c2c[R1]ccc2c1Br</smiles>

5

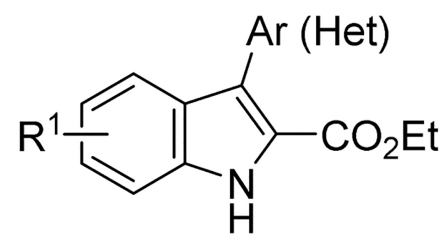

6

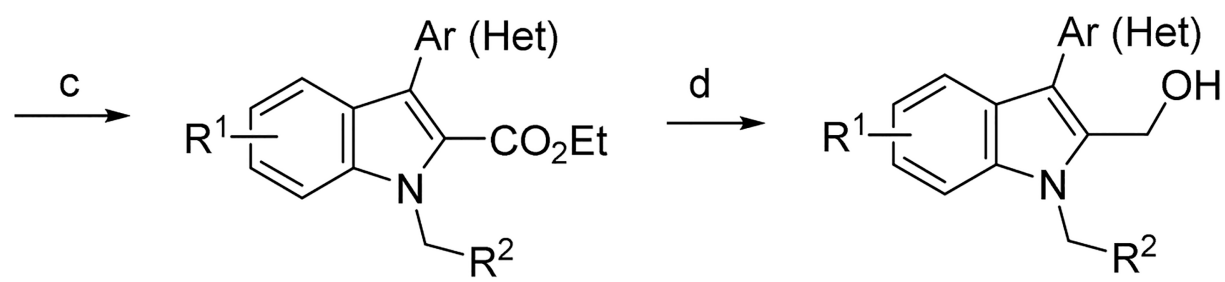

7

8

Scheme 1.

Synthesis of PAR4 Antagonist Analogues $8^{a}$

${ }^{a}$ Reagents and conditions: (a) THF, NBS (1.0 equiv), $0{ }^{\circ} \mathrm{C}, 1 \mathrm{~h}, 90-99 \%$; (b) aryl/ heteroarylboronic acid (1.5 equiv), $\mathrm{Pd}\left(\mathrm{PPh}_{3}\right)_{4}$ (0.1 equiv), $\mathrm{Na}_{2} \mathrm{CO}_{3}$ (2.0 equiv), $\mathrm{DMF}-\mathrm{H}_{2} \mathrm{O}$ (4:1), $\mu \mathrm{w}, 120{ }^{\circ} \mathrm{C}, 15 \mathrm{~min}, 76-95 \%$; (c) $\mathrm{K}_{2} \mathrm{CO}_{3}$ (2 equiv), benzyl or alkyl bromide (2 equiv, DMF, $45^{\circ} \mathrm{C}, 16 \mathrm{~h}, 60-90 \%$; (d) LAH, THF, $0{ }^{\circ} \mathrm{C}, 1 \mathrm{~h}, 50-85 \%$. 
Table 1

Initial SAR of Analogues 9

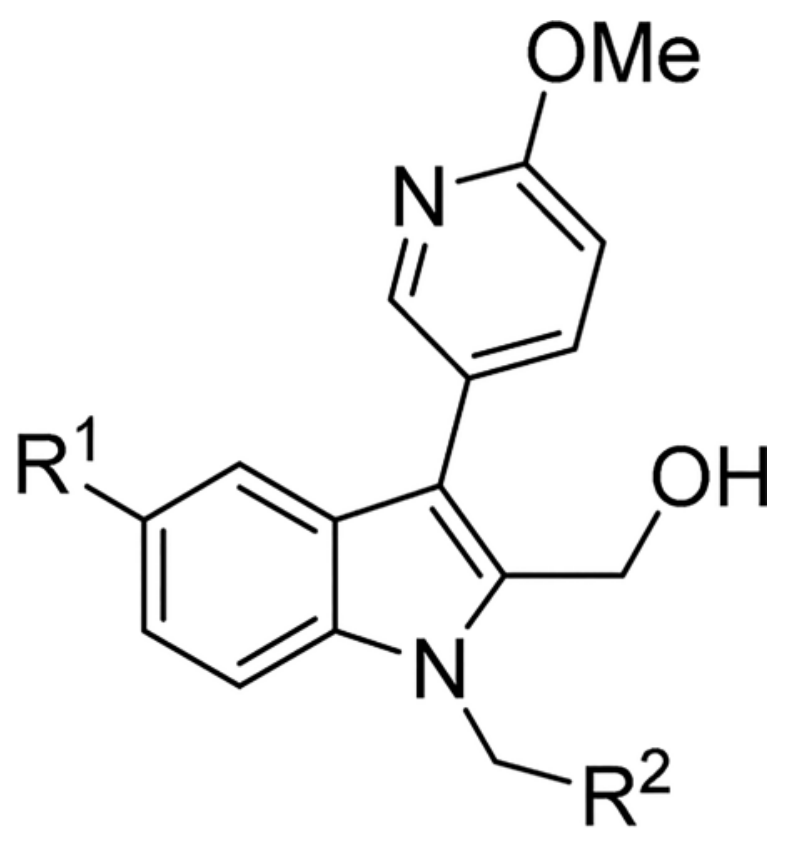

9

\begin{tabular}{cllrc}
\hline compd & $\mathbf{R}^{\mathbf{1}}$ & $\mathbf{R}^{\mathbf{2}}$ & $\begin{array}{r}\text { PAR4-AP \% } \\
\text { max PAC-1 } \boldsymbol{a}\end{array}$ & $\begin{array}{c}\text { PAR4-AP PAC-1 IC } \\
\mathbf{5 0} \\
(\boldsymbol{\mu M}), \mathbf{p I C}_{\mathbf{5 0}} \pm \mathbf{S E M}^{\boldsymbol{b}}\end{array}$ \\
\hline $\mathbf{9 a}$ & $\mathrm{CF} 3$ & $\mathrm{H}$ & 106.5 & $>10$ \\
$\mathbf{9 b}$ & $\mathrm{OCF}_{3}$ & $\mathrm{Ph}$ & 53.4 & $>10$ \\
$\mathbf{9 c}$ & $\mathrm{OCF}_{3}$ & 2-FPh & 89.0 & $>10$ \\
$\mathbf{9 d}$ & $\mathrm{CF}_{3}$ & $3-\mathrm{OMePh}$ & 108.5 & $>10$ \\
$\mathbf{9 e}$ & $\mathrm{OCF}_{3}$ & $3-\mathrm{FPh}$ & 80.6 & $>10$ \\
$\mathbf{9 f}$ & $\mathrm{OCF}_{3}$ & $2,4-\mathrm{diFPh}$ & 19.7 & $5.11,5.29 \pm 0.33$ \\
$\mathbf{9 g}$ & $\mathrm{OCF}_{3}$ & $3-\mathrm{CF} 3 \mathrm{Ph}$ & 19.7 & $4.82,5.32 \pm 0.04$ \\
$\mathbf{9 h}$ & $\mathrm{OCF}_{3}$ & $3-\mathrm{ClPh}$ & 95.5 & $>10$ \\
$\mathbf{9 i}$ & $\mathrm{OCF}_{3}$ & $3-\mathrm{BrPh}$ & 27.1 & $2.19,5.66 \pm 0.33$ \\
$\mathbf{9 j}$ & $\mathrm{OCF}_{3}$ & $2-\mathrm{ClPh}$ & 4.95 & $0.45,6.31 \pm 0.05$ \\
\hline
\end{tabular}

${ }^{a}$ Initial single point screens were conducted using $10 \mu \mathrm{M}$ analogue, and values indicate the percentage of max PAC-1 binding after PAR4-AP stimulation of human platelets.

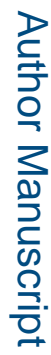

${ }^{b}$ Average of three independent determinations. 
Table 2

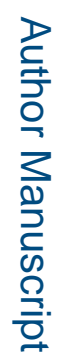

Initial SAR of Analogues 10

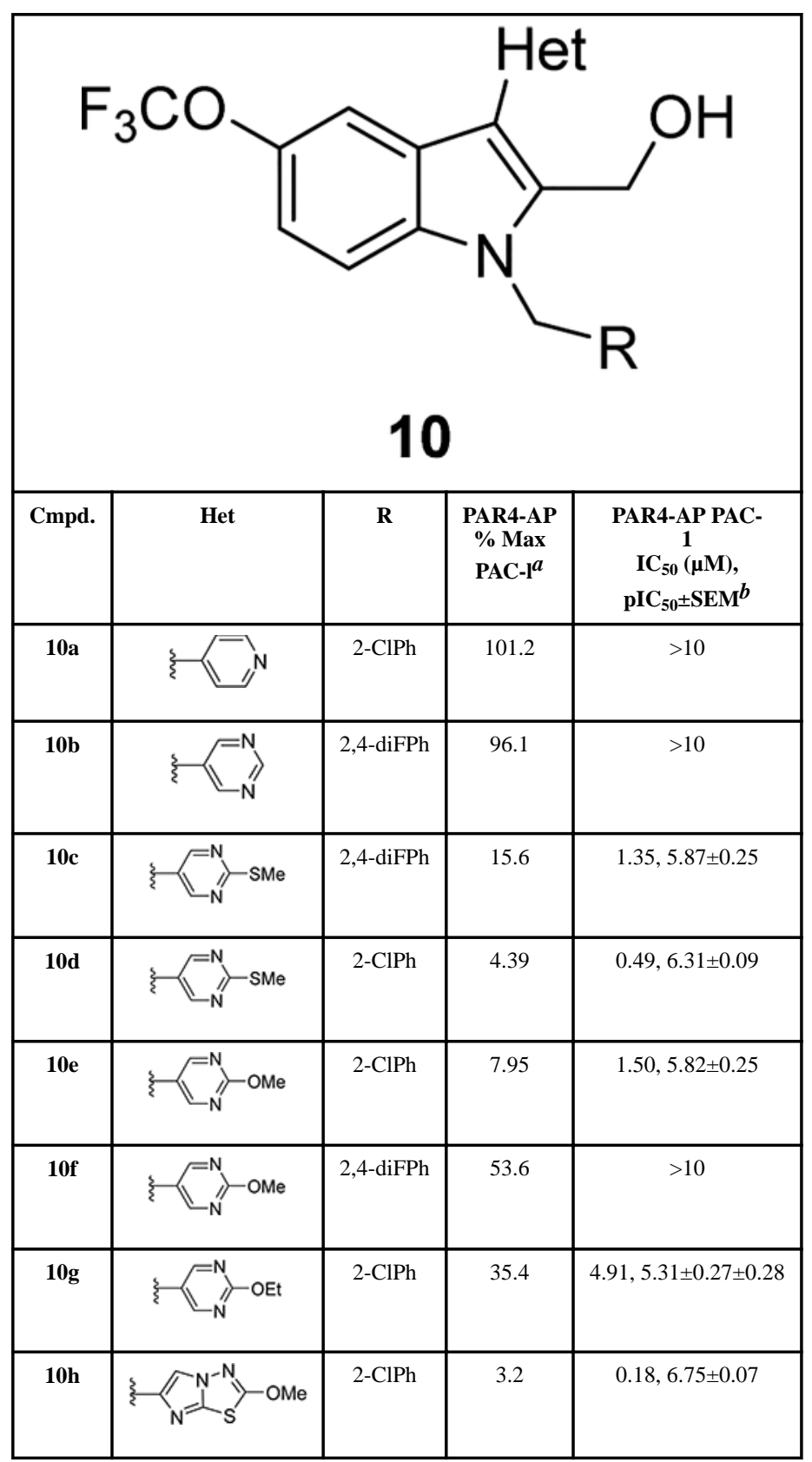

${ }^{a}$ Initial single point screens were conducted using $10 \mu \mathrm{M}$ analogue and values indicate the percentage of Max PAC-1 binding after PAR4-AP stimulation of human platelets.

${ }^{b}$ Average of three independent determinations. 
Table 3

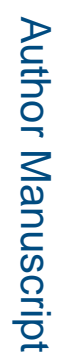

Initial SAR of Analogues 11

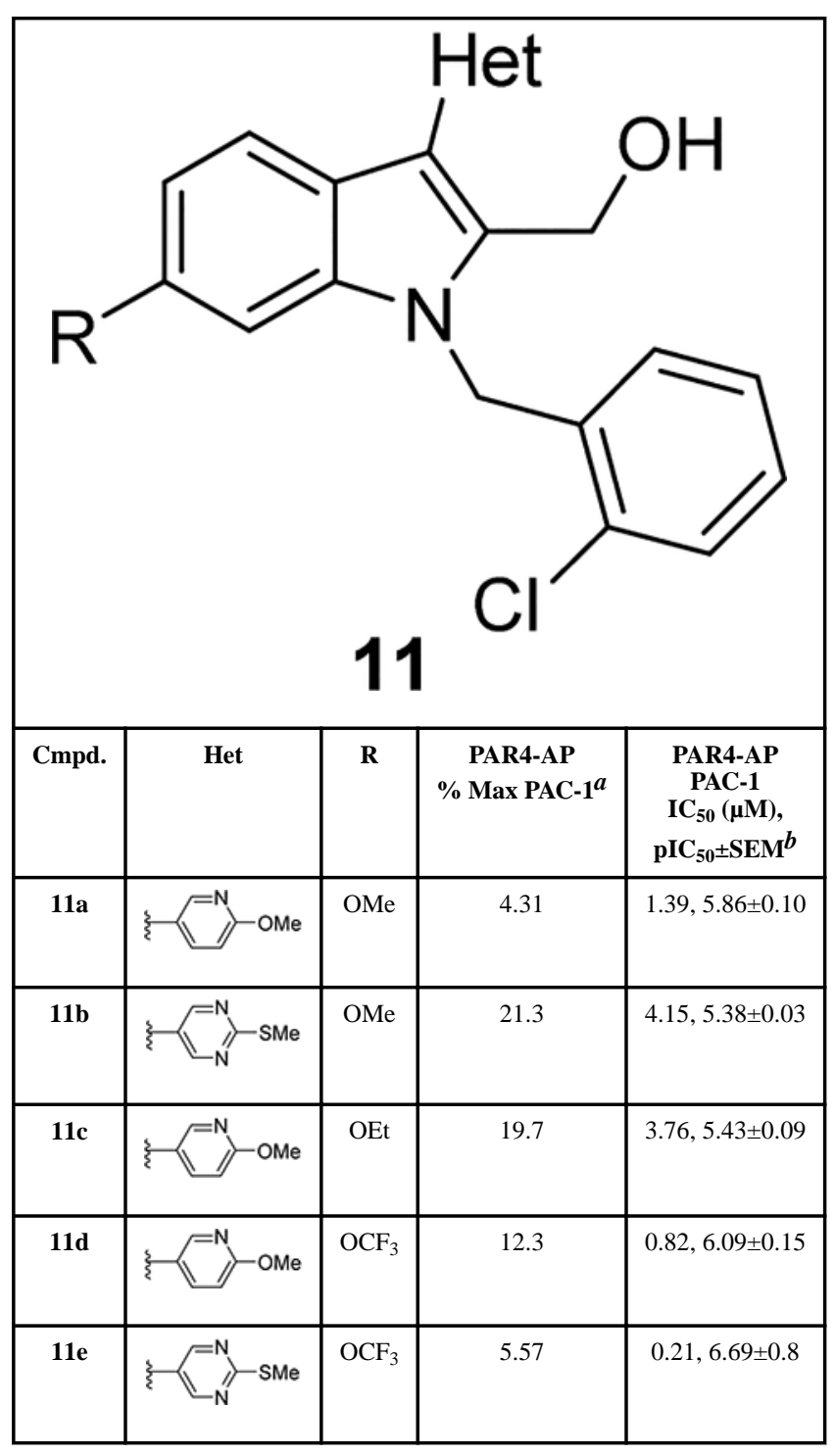

Initial single point screens were conducted using $10 \mu \mathrm{M}$ analogue, and values indicate the percentage of max PAC-1 binding after PAR4-AP stimulation of human platelets.

${ }^{b}$ Average of three independent determinations. 
Table 4

DMPK Characterization of Select PAR4 Antagonists

\begin{tabular}{llll}
\hline & $\mathbf{9 j}$ & $\mathbf{1 0 d}$ & $\mathbf{1 0 h}$ \\
\hline MW & 462.8 & 479.9 & 508.9 \\
TPSA & 54.2 & 57.3 & 69.8 \\
cLogP & 5.2 & 5.3 & 5.1 \\
CYP $(1 \mathrm{~A} 2,2 \mathrm{C} 9,2 \mathrm{D} 6,3 \mathrm{~A} 4) \mathrm{IC}_{50}(\mu \mathrm{M})$ & $4.2,6.8,0.12,14$ & $2.9,6.1,<0.1,17.6$ & $>30,11.2,1.2,>30$ \\
In Vitro PK & & & \\
rat $\mathrm{CL}_{\mathrm{HEP}}(\mathrm{mL} / \mathrm{min} / \mathrm{kg})$ & 45.1 & 58 & 36.1 \\
human $\mathrm{CL}$ & 18.5 & 1.1 \\
rat PPB $(\mathrm{mL} / \mathrm{min} / \mathrm{kg})$ & 5.3 & 0.001 & 0.003 \\
human PPB $\left(f_{\mathrm{u}}\right)$ & 0.04 & 0.002 & 0.004 \\
in Vivo Rat PK $(\mathrm{IV} \mathrm{Cassette,} 0.2 \mathrm{mg} / \mathrm{kg}, 0-6 \mathrm{~h})$ & & \\
$t_{1 / 2}(\mathrm{~h})$ & 2.83 & 0.25 & 6.1 \\
$\mathrm{CL}$ & $(\mathrm{mL} / \mathrm{min} / \mathrm{kg})$ & 380 & 45 \\
$V_{\mathrm{ss}}(\mathrm{L} / \mathrm{kg})$ & 118 & 5.82 & 21.1 \\
\hline
\end{tabular}

